\title{
Towards a Conceptual Framework for Political Leadership Theory and Practice: A Thematic Analysis of the Literature
}

\author{
Duke Ohene Ofosu-Anim*, Seung-Hee Back \\ Leadership Department, Yemyung Graduate University, Seoul, South Korea \\ Email: *duke@ygu.ac.kr
}

How to cite this paper: Ofosu-Anim, D. O., \& Back, S. -H. (2021). Towards a Conceptual Framework for Political Leadership Theory and Practice: A Thematic Analysis of the Literature. Open Journal of Leadership, 10, 193-213.

https://doi.org/10.4236/ojl.2021.103013

Received: June 23, 2021

Accepted: July 30, 2021

Published: August 2, 2021

Copyright ( 2021 by author(s) and Scientific Research Publishing Inc. This work is licensed under the Creative Commons Attribution International License (CC BY 4.0).

http://creativecommons.org/licenses/by/4.0/

\begin{abstract}
While there is agreement on the relevance of political leadership theory and practice, there is still deficiency in literature on viable approaches, enabling factors, and suitable personality characteristics. Suggested models for political leadership are mostly untested, which make their applicability and effects largely unknown. This paper proposes development of a conceptual framework and discusses how it can be used to design a model for political leadership. A thematic review of literature on political leadership identified 27 different theories and practices which elucidated fully or partially the components of political leadership theory and practice. The models were subjected to a thematic analysis to identify themes used in political leadership. The results were used to develop a conceptual framework. Two themes and four processes of political leadership were identified. From these results, a conceptual framework for political leadership theory and practice was developed. The framework illustrates the two components of the political leadership theory and practice while indicating a multidisciplinary set of relationships. As such the framework allows for individual themes to occur repeatedly through the political leadership continuum. The results of the study can serve as a preliminary model for developing an extended understanding of the theory and practice of political leadership, and also be used in disciplines such as political science, economics, sociology, and psychology, as a guide in determining inter-relational dynamics in political leadership patterns, behaviors, and character traits of leaders in future studies. The framework provides a foundation for gathering evidence from scenario-based case studies on the political leadership function. Attempts at utilising thematic analysis to develop a framework for ascertaining congruence between political leadership theory and practice is a new concept and it calls for further future study to improve the framework with an aim of advancing its practicality in explaining the concepts.
\end{abstract}




\section{Keywords}

Political Leadership Theory, Political Leadership Practice,

Political Leadership Model

\section{Introduction}

The distinction between a political leader and a politician is not a debatable one (Joensuu \& Niiranen, 2018). As opined by (Teles, 2012), whereas the political leader possesses both the passion and responsibility, the politician is normally associated with achieving political goals without necessarily aligning means, ends, and consequences. This distinction performs two functions, in that, on one hand, even though both personalities may hold the same or similar offices, it separates intentions of the individual from roles based on approaches to executing mandate and not on functions, and on the other hand, the superiority of leading as against accomplishing in a political setting is emphasized. (Teles, 2012) additionally clarifies that political leadership is a game-changer, in that many social outcomes are heavily dependent on it. The imperative role of political leadership has been re-echoed severally, and there is ample literature which supports this assertion see (Gane, 1997; Yukl, 2002; Peele, 2005). Political leadership is perceived by (King et al., 2015) as an important and indispensable element to societal advancement and development. (King et al., 2015) additionally, reiterate the important role of political leadership in ensuring and facilitating peace and social security. The absence of, or ineffective political leadership systems and structures have been known to create a festering vacuum where disorder, chaos, and trepidation thrive (Harriss, 2000). The necessity of political leadership in the moulding and shaping the fortunes of society has long been underscored see (Harriss, 2000; Saideman et al., 2002; Williams et al., 2009). Based on the above, the study of political leadership as a function can be said to affect and encompass several aspects of the society bringing together disciplines including but not limited to psychology, economics, political science, and sociology see (Kirvalidze \& Samnidze, 2016).

However, regardless of the inter-disciplinary nature of political leadership, conceptual and theoretical literature on political leadership which encompasses relevant disciplines remain scarce and scanty (Hartley, 2012) with limited literature attempting to address classical theories of political leadership see (Molchanov, 2016; Myres, 2016; Cornell \& Malcomson, 2016) and contemporary theories of political leadership see (Masciulli \& Knight, 2016; Andrew, 2016; Knight, 2016; Sjoberg, 2016). (Hartley, 2012) explains that literature on political leadership is sparse and contrasting because political scientists have long neglected the concept of political leadership while the focus has mainly been on organisations, systems and administrations, additionally, experts consider politicians as merely policy makers and public servants, and as such their roles should focus on policy 
execution and management with little consideration on the leadership aspect within the political function. Inability to determine operative definitions, effective theories, and functional models for political leadership theories and practice which will yield desirable public goals has been a key determining factor for worsening social inequalities in several economies (Sahn \& Stifel, 2003). (Schoen, 2013) indicates that often times the problem of political leadership stems from the political system itself which may have been infested by political corruption and crony capitalism. This assertion is further recapped by (Akuffo \& Kivipõld, 2017) in their detailed explanation of how leadership behaviour influences nepotism, cronyism, and favouritism. In an attempt to address this deficiency, there have been many calls for political reforms as a remedy to 1) improve democracy and social inclusion (Manor, 2004); 2) expansion of government accountability (Bates, 2005; Tömmel \& Verdun, 2017); 3) strengthen the importance of public opinion (Titley, 2003); 4) attract foreign investment (Fielding, 1997).

This study mainly seeks to review and assess nuances, differentiations, meanings, definitions, and terminologies on existing literature related to political leadership with the aim of suggesting a conceptual framework that will serve as an archetype for future scrutiny and improvement towards developing an interdisciplinary theory for political leadership.

The study is structured into eight sections. The sections are arranged in the following manner. The first section introduces the study and provides a background to the main ideas and concepts under study, the second section provides a review of relevant literature on related literary material. Section three presents the methodology employed and methods utilized to collect data. Section four discusses research results, while section five draws conclusions on the outcomes of the study. Section six proffers limitations encountered during the study and potential for further study on the subject. Finally, section seven outlines possible conflicts of interest and section eight, which details the references used in the study and completes the paper.

\section{Literature Review}

Developing an inter-disciplinary model for political leadership which overhauls the political system to improve societal standards and deepen democracy is not a simple assignment. As indicated by (Rakner et al., 2007) in refuting earlier modernisation theory suggest that a certain minimum level of development is a pre-requisite for democratisation, and also emphasize that, even though political reformation has begun in several developing countries, too much attention is paid to electoral reforms which leave structural and institutional reforms often unattended to, also see (Elgie, 2017; Helms, 2017). (Rakner et al., 2007) proceed to underscore the relevance of a comprehensive political reform which encompasses all aspects of the political process and includes individuals, structures, and processes with consideration to other areas of the economy which may have cer- 
tain influences on political reformation. In analysing the importance of individual qualities of leaders in the political process, (Manor \& Duckett, 2017) conclude that there could be a negative or positive impact of political leaders on social outcomes based on their "adroit machinations" or "ineptitude". Also, the role of structures and institutions is essential to the political function as it serves as a source of power and cooperation to the political leader (Moe, 2005). (Torfing et al., 2019) also stress the importance of the process on political leadership by elaborating its ability to help in defining problems, and designing and implementing solutions.

Another aspect of the political leadership role is that it is key in ensuring a decent livelihood for society (Aloor, 2020). As (Álvarez-Díaz et al., 2010) indicate, different approaches to public policy by governments based on their political ideologies and orientations have strong impact on the level of satisfaction of citizens from an economic, social, and cultural perspective, in effect, the more governments strive to put in place social protection measures for its citizens, the more the contentment levels of it citizens increase. The political system, in the shape of processes and institutions, is as important as the political leader, as both have been identified as key elements in the mechanisms of economic growth and development. (Williams et al., 2009) in clarifying the connection between politics and growth emphasize that conducting institutional strengthening to build a culture of trust between politicians and investors, and putting in place a system of checks and balances to counter conflict of interest are necessary measures to hold political leaders in check if growth is to be achieved. (Williams et al., 2009) also opine that to improve the political process, restraining problems such as "predation, rent-seeking, and patronage" (p. 29) must be avoided. (Rontos et al., 2013) on the other hand propose that for sustainable strategies towards attainment of low corruption and high income to work, there must be democratic transformation which is characterized by a free political system. Additionally, in a study (Lee, 1991) finds that participatory democracy is accompanied by economic development and industrialization. (Weingast, 1995) proposes a safe political foundation and a deliberate economic system as necessary requirements for thriving market, and further claims that to achieve this, there is a need to build strong political institutions that can reliably commit the state to honour economic and political rights of its citizens. (Radu, 2015) in analyzing the interplay between economics and politics and their overall effect on economic growth concludes that "political stability and political certainty have a positive impact on economic growth" (p. 1995). (Paldam, 1998), however, investigates politics and economic growth from an inverse perspective by inquiring whether economic growth can lead to political stability. (Paldam, 1998) finds that in instances where the system of government is democratic, economic growth leads to strengthened political stability, but in authoritarian societies, economic growth leads to civil unrest which may ultimately lead to political instability. In an earlier study, (Sedehi \& Tabriztchi, 1974) suggest an interrelationship be- 
tween economic change and political change. (Sedehi \& Tabriztchi, 1974) claim that economic growth is normally marked by "industrialisation, urbanisation, literacy, and mass-media communication" (p. 424). These advancements increase political awareness within the society which leads to increasing demands for feasible political involvement and systems. In order for political leaders to function in a fair and effective manner, there is a need to strengthen public/political institutions. (Scalapino, 1992) describes formation of formal political institutions as regularising and rendering predictable the practice of governance. (Moe, 2005) further divides the purpose of political institutions into two broad categories: i.e. to "mitigate collective-action problems and weapons of coercion and redistribution" (p. 213). As remarked by (De Mesquita et al., 2002), public policy choices by political leaders are determined by the design of public institutions. (Cook, 1998) claims that "public administration is a political institution" (p. 225) and further calls for a change in focus which will require new leadership approaches and learning as a result of this concept. (Gerring \& Thacker, 2004) find that certain democratic systems of government help strengthen political institutions by creating an environment of openness, competition, and transparency which help reduce political corruption. (Saideman et al., 2002) conclude that political institutions are essential to reducing ethic violence within a democratic setting. (Anderson \& Guillory, 1997) investigate the effect of political institutions on citizen satisfaction with democracy and find that whereas losers of democratic competition may be less satisfied and vice versa, however, there is a general increase (regardless of one's political leanings) in satisfaction levels of citizens when political institutions exhibit consensual tendencies towards decision making and nation building. (Enikolopov \& Zhuravskaya, 2007) find that strengthening political institutions significantly improves fiscal decentralisation outcomes such as economic growth and quality of government, and conversely, appointing local politicians instead of electing results in a decrease in fiscal decentralisation.

Generally, there is an agreement that there exists a strong relationship between the character of the political leader, the political environment, the public, and realisation of political goals (Solovyov, 2017). There is also a general consensus that political leadership study span several disciplines, and consequently to effectively develop a political leadership model there is a need to approach the exercise from a multi-disciplinary standpoint. This further draws attention to the relevance of formulating a concept which encompasses all of these factors into a conceptual framework.

\section{Methodology}

The structure and format of our research method are based mainly on thematic analysis see (Braun \& Clarke, 2012). This approach finds its substructure on a thematic study conducted by Ward, House and Hamer in August 2009. We started by conducting a preliminary literature review which uncovered a num- 
ber of complications. First, political leadership is denoted using several terminology, with associated analogous and interchangeable usage of the term. For instance, other terminologies used instead of political leadership include political power (Moe, 2005), political legitimacy (Schoen, 2013), political authority (Bennister et al., 2015; Bennister et al., 2017), likewise sovereignty (Prokhovnik, 2009), and governance (Hendriks, 2009; Pierre \& Peters, 2019) are also widely used, which means that our review had to be based on a wide range of related terminology.

Furthermore, "political leadership" thought was developed within the literature in diverse ways. In some instances, research results viewed political leadership as coercive and generative form of power which may be applied depending on the prevailing situation (Hendriks, 2009) while in others leadership is viewed as a core property of a functioning democracy (Beerbohm, 2015). These assessments of political leadership can be seen mostly in the literature on legitimisation of political activity (Butcher \& Clarke, 2006) or in response to challenging events (de Clercy \& Ferguson, 2016). On the other hand, political leadership is considered to be mobilisation of resources to satisfy motives (Burns, 1978). The dispensation of suitable political leadership which facilitates desirable outcomes are particularly recognised within political economy literature (Curry-Stevens, 2007; Torfing \& Ansell, 2017; Lees-Marshment, 2016). Given the aforementioned, our review had to incorporate models and practices of political actions, national governance, and regime formation.

Finally, literature on political leadership theory and practice is spread across fields such as psychology, political science, economics, environmental studies, anthropology, and agriculture. While several literature reviews are able to effectively reduce the array of their search areas and records, it was important for our review to source literature from a wider group which made us search through a broader range of backgrounds. To ameliorate the difficulties detailed earlier, we chose a thematic approach which includes summarising, analysing, and synthesising evidence from literature (Ward et al., 2009). The researchers included the central themes within the political leadership field, which were ensured by detecting the areas which seem critical to political leadership theory and practice. In line with (Ward et al., 2009), the researchers considered a four-stage approach: exploration of abstracts; selection of articles for further reading; identifying repetitive topics from selected articles; and summation of topics to develop a conceptual framework for political leadership theory and practice. For the purpose of our review, we defined political leadership theory and practice as how political actors through interactions with public and institutions function with the aim of accomplishing approval and goals.

\subsection{Search Strategy}

The first step of the search strategy was developed by reviewing selected related papers. This was to assist the researchers identify and determine themes for the 
search plan. The papers used in this exercise were excluded from the main search exercise. These papers were identified in two ways: 1) recommendations by professionals in the field and 2) through chain sampling which was identified within the references of references. The reviewed papers included literature reviews, empirical studies, official reports and study manuals. It was identified that the papers used 20 different terms (Table 1) to describe the concept of political leadership or to describe similar terms. We deciphered these terms into 15 different commands (Table 2) which were then used to search 10 different academic databases including DOAJ, JSTOR, SAGE, Taylor and Francis, Google Scholar, Semantic Scholar and other research-driven social science review portals. We limited the search fields to politics, psychology, economics and sociology.

The preliminary search which was conducted in March 2020, produced 7452 search results, which were further refined through a process of second-tier search. This involved omitting the areas of business, education, agriculture, and innovation, which focused on corporate governance, curriculum development, agricultural transformation, and innovation economy respectively, while including papers which included 10 of the search items that appeared the most in title or abstract. This process resulted in the identification of 231 papers.

Table 1. Terms used to describe political leadership or similar terms.

\begin{tabular}{cccc}
\hline No & Term & No & Term \\
\hline 1 & Ministerial & 11 & Power \\
2 & Governmental & 12 & Administration \\
3 & Public & 13 & Authority \\
4 & State & 14 & Hegemony \\
5 & Partisan & 15 & Regime \\
6 & Civic & 16 & Jurisdiction \\
7 & Legislative & 17 & Command \\
8 & Election & 18 & National \\
9 & Legitimacy & 19 & Democracy \\
10 & Country & 20 & Sovereignty
\end{tabular}

Table 2. Deciphered search commands.

\begin{tabular}{cccc}
\hline No & Term & No & Term \\
\hline 1 & Democratic leadership & 9 & Political landscapes \\
2 & Public leadership & 10 & State building \\
3 & National leadership & 11 & National governance \\
4 & Electoral cycle/system & 12 & Political governance \\
5 & Presidential leadership & 13 & Public governance \\
6 & Political institutions & 14 & Public administration \\
7 & Multilevel governance & 15 & Public management \\
8 & Political markets & & \\
\hline
\end{tabular}




\subsection{Selection of Articles}

We selected articles for in depth reading using purposive sampling, which began with reviews of literature which seek to expound the phenomenon. With an aim of developing a framework covering broad ideas which may be considered vital, we also selected articles which advanced knowledge on issues of government or national governance, and political-office holders explaining all or part of the processes. Finally, we selected articles that explicitly focused on political governance processes, as these appeared to be a particularly important aspect of political leadership, but often treated distinctly. Selection in all three cases was conducted until we reached a point of saturation when most of the literature duplicates the main messages see (Ward et al., 2009; Nowell et al., 2017; Castleberry \& Nolen, 2018). We selected 75 papers for this exercise out of which 61 were read thoroughly. We complimented this exercise with continual search through databases and review of reference list until July 2020.

\subsection{Thematic Analysis}

A total of 61 materials which include articles and reports were read thoroughly. For each we used a uniform outline to sum up the objective or main purpose of the paper (e.g. political leadership behaviour, political leadership functionality, and forces of leadership), the main results or arguments made in the paper (such as elements of political leadership for public participation and review of political leadership themes) form the basis for value, importance and originality of this paper. Through the detailed appraisal of these articles and reports, we identified 27 different models and approaches which explained in whole or in part the theory and practice of political leadership. Since the aims of these models were to capture the main constituents of political leadership, we used them as a basis for identifying recurring themes. This included exposing the models to thematic analysis to identify the individual components and the type of processes used in utilising effective political leadership. The 27 models are listed in Table 3.

\section{Results and Discussion}

\subsection{Political Leadership Components}

The thematic analysis of the 27 models identified two themes of political leadership theory and practice:

- Behavioural and traits perspective;

- Deliberative and consultative perspective.

As noted by (Ishii, 2011), there is a need to integrate behaviour and trait theories in the research of political leadership. In line with this, fourteen of the sources focused on behavioural and traits approaches which is the first theme identified. This was expressed in a variety of ways including moral realism (Yan, 2016), credibility (Van Zuydam, 2014; Van Zuydam \& Hendriks, 2018), motivation (Bryder, 2001), and loyalty and reputation (Myerson, 2011) among 
Table 3. Details of the 27 models explaining political leadership.

\begin{tabular}{lc}
\hline No & Source \\
\hline & Ammeter, A. P., Douglas, C., Gardner, W. L., Hochwarter,
\end{tabular}

1 W. A. \& Ferris, G. R. (2002). Toward a political theory of leadership. The Leadership Quarterly, 13 (6), pp. 751-796

Aragonès, E., Postlewaite, A., \& Palfrey, T. (2007). Political

2 reputations and campaign promises. Journal of the European Economic Association, 5(4), 846-884.

3 Beerbohm, E. (2015). Is Democratic Leadership Possible? American Political Science Review, 109(4), pp. 639-652.

Bennister M., 't Hart, P. \& Worthy, B. (2015). Assessing the

4 authority of political office-holders: the leadership capital index. West European Politics, 38 (3), pp. 417-440.

Butcher, D. \& Clarke, M. (2006). Political leadership in

5 democracies: some lessons for business?

Management Decision, 44 (8), pp. 985-1001.

6 Bryder, T. (2001). Motivational Approaches to the Study of Political Leadership. Political Science, 104 (2).

Curry-Stevens, A. (2007). Pedagogy for the privileged: Building civic virtues in political leaders. Available at:

7 http://www.tlc.oise.utoronto.ca/conference2003/Proceedings/ Curry-Stevens.pdf

de Clercy, C. \& Ferguson, P. (2016). Leadership in precarious

8 contexts: Studying political leaders after the global financial crisis. Politics and Governance, 4 (2), pp. 104-114.

Garfield, Z.H., von Rueden, C. \& Hagen, E. H. (2019). The

9 evolutionary anthropology of political leadership.

The Leadership Quarterly, 30 (1), pp. 59-80.

10 Hendriks, C. M. (2009). Deliberative governance in the context of power. Policy and Society, 28 (3), pp. 173-184.

Horton, J. (2007). Political leadership and contemporary

11 liberal theory. In: Political leadership: a missing link element in democratic theory', European Consortium for Political Research Joint Sessions, Helsinki, Finland, 7-12 May 2007.

Ishii, K. (2011). Analysis of political leadership using the

12 questionnaire method.

Mejiro Journal of Humanities, 7, pp. 75-85.

13

Ishii, K. (2010). Theory of Political Leadership. Mejiro Journal of Humanities, 6, pp. 61-74.

Lees-Marshment, J. (2016). Deliberative political leaders:

14 The role of policy input in political leadership.

Politics and Governance, 4(2), pp. 25-35.

Körösényi, A., Illés, G. \& Metz R (2016). Contingency and

15 political action: The role of leadership in endogenously created crises. Politics and Governance, 4 (2).

Manor, J. \& Duckett J. (2017). The significance of political

16 leaders for social policy expansion in Brazil, China,

India and South Africa.

Commonwealth \& Comparative Politics, 55 (3), pp. 303-327.
Political leadership is defined as the

Category

constructive management of shared meaning.

Deliberative and

consultative perspective

The reputation of a political leader depends

on the degree to which promises are credible.

Behavioural and

Proposes shared commitment as

the basis of democratic leadership

Deliberative and consultative perspective

Uses LCI to review aggregate

authority of political leader

Behavioural and

traits perspective

Suggests a political institutional approach to leading.

Leaders can use motivation to empower the underprivileged.

Use of pedagogy to transform the privileged towards building civic virtues.

Deliberative and consultative perspective

Behavioural and traits perspective

Deliberative and consultative perspective

Proposes a decentralist perspective to challenging events.

Deliberative and consultative perspective

Relationship between evolution, ecology, and culture as they related to political leadership.

Behavioural and traits perspective

Deliberative democracy relate to both coercive and generative forms of power.

Deliberative and consultative perspective

Underscores the often overlooked importance of human agency in political leadership.

Deliberative and consultative perspective

Proposes integration of behaviour and trait theory in the research of political leadership.

Behavioural and traits perspective

Proposes three kinds of political leadership: creative, administrative, and symbolic.

Demonstrates that government ministers take a deliberative approach to decision making.

Introduces a third approach-voluntarist-for political leaders in crisis management situations.

Underscores the importance of political agency, prioritisation and adoption of certain issues.
Behavioural and traits perspective

Deliberative and consultative perspective

Behavioural and traits perspective

Deliberative and consultative perspective 


\section{Continued}

17 Human Relations, 59 (4), pp. 483-504.

Munro, I. \& Thanem, T. (2018). The ethics of affective

18 leadership: Organizing good encounters without leaders. Business Ethics Quarterly, 28(1), pp. 51-69.

Myerson, R. (2011). Toward a theory of leadership and state

19 building. In Proceedings of the National Academy of Sciences, 108 (Supplement 4), pp. 21297-21301.

Paramova, P. \& Blumberg, H. (2017). Cross-cultural variation

20 in political leadership styles. Europe's Journal of Psychology, $13(4)$, p.749.

Prokhovnik, R. (2009). Political leadership and sovereignty. In

21 Political leadership: a missing link element in democratic theor European Consortium for Political Research Joint Sessions, Helsinki, Finland, 7-12 May 2007.

22

Teles, F. (2012). Political leaders: The paradox of freedom and democracy. Revista Enfoques, 10 (16), pp. 113-131.

Torfing, J. \& Ansell, C. (2017). Strengthening political leadership and policy innovation through the expansion of collaborative forms of governance.

Public Management Review, 19 (1), pp. 37-54.

Torfing, J. \& Sørensen, E. (2019). Interactive political leadership in theory and practice: How elected politicians may benefit from co-creating public value outcomes. Administrative Sciences, 9(3), 1-18.

van Zuydam, S. (2014). Credibility as a source of political capital: exploring political leaders' performance from

25 a credibility perspective. In Political capital and the dynamics of leadership: exploring the leadership capital, European Consortium for Political Research Joint Sessions, 2014.

van Zuydam, S. \& Hendriks, F. (2018). Credibility enacted: Understanding the meaning of credible political leadership in the Dutch parliamentary election campaign of 2010. Journal of Political Marketing, 17(3), pp. 258-281. The Chinese Journal of International Politics, 9 (1), pp. 1-26.
Political leadership is denoted by interdependent networks of social relations.

Argues against underplay of ethical capabilities of followers in ethical leadership literature.

Loyal supporters expect political leaders to be reputable.

Transformational leadership behaviours are universal across cultures.

Defines political sovereignty as how negotiation takes place in a political society.

Voters look-up to dominance of assertive leaders during voting decision-making.

Collaborative governance can enhance political leadership and policy innovation.

Politicians strengthen their political leadership role through leading co-creation of public value outcomes.

Credibility as political capital is essential to political leadership.

Extends credibility approach with a dramaturgical approach in building political leader credibility.

Moral realism suggests that a state's strength determines strategic interests and political leadership determine strategies to achieve those interests.
Deliberative and consultative perspective

Behavioural and traits perspective

Behavioural and traits perspective

Behavioural and traits perspective

Deliberative and consultative perspective

Behavioural and traits perspective

Deliberative and consultative perspective

Deliberative and consultative perspective

Behavioural and traits perspective

Behavioural and traits perspective

Behavioural and traits perspective

others (Paramova \& Blumberg, 2017; Garfield et al., 2019). Each model deals with behavioural and traits perspective differently. While (Van Zuydam, 2014) extends the demonstration of the need for political leaders' credibility by introducing dramaturgical approaches to performance communication, (Teles, 2012) identifies the nature and distinctiveness of contemporary political leadership through the lenses of dominance of political leaders. (Ishii, 2010) breaks the trait of political leadership into two broad typologies-natural and acquired elements, and stresses that there are three parts to the natural elements which were 
termed creative, administrative, and symbolic, while denoting parts of acquired elements as intellect and virtue. All of the sources which accounted for this perspective showed that behavioural and traits emanate from the leader for the benefit of the audience or follower. However, (Munro \& Thanem, 2018) provide furtherance by highlighting the deficiency of leadership studies in underplaying the ethical capacities of followers by presuming they are in need of direction and care by morally superior leaders. (Munro \& Thanem, 2018) advocate affective leadership which involves both leaders and followers in the pursuit of joyful encounters as the most efficacious way to leading the public.

Regarding the second theme identified, thirteen of the models included consideration of deliberative and consultative approaches to political leadership. (Ganuza Fernández, 2012) describes deliberative theory as the legitimisation of societal power through pluralism and equality. It was identified that the notion behind deliberative perspective to political leadership stems from the utilisation of co-creation of public values (Torfing \& Sørensen, 2019), shared commitment (Beerbohm, 2015), deliberative governance (Hendriks, 2009), and interdependent networks of social relations (Morrell \& Hartley, 2006). Other models focused on contesting previously held concepts and notions about political leadership. For example, (Ammeter et al., 2002) demonstrate how political perspective should not position leaders as ambitious and manipulative figures but consider their contributions as working through an organisational leadership continuum which is determined by constructive management of shared meaning. (Lees-Marshment, 2016) discredits earlier notions that political leaders are "all-knowing", by presenting that modern politicians are accepting that they do not have all the answers and abilities and are moving towards incorporating public input. Similarly, (Torfing \& Ansell, 2017) propose a collaborative policy innovation which introduces fresh ideas as a solution for political leaders who are on one hand embattled by a myriad of problems and on the other are dependent on unproductive policies.

\subsection{Political Leadership Process}

In addition to identifying two components, our thematic analysis of the literature also revealed that the components can be organised four political leadership processes. These were categorised as follows:

1) Promise;

2) Mandate;

3) Representation;

4) Causation.

The paper proposes a cyclical linear model of political leadership process which forms the basis of practice. The process is marked by steps with a beginning and an end, but with the possibility of a re-start depending on the extent of satisfaction levels of the voting public. In conformity to this, the study identified political promise as the first step within the political leadership process. Political promise is a critical stage within the process, in that the acquisition of 
the political authority and legitimacy, depends on how effectively politicians communicate their promises to the public, and is supported by (Aragonès et al., 2007) who establish that the public tends to punish politicians who fail to fulfil their political promises. This notion is further reiterated by (Markwat, 2014) who explains that the public uses the political promises given to make informed decisions in identifying the most suitable candidate to represent their opinions and address their needs, this is similar to the claim by (Cruz et al., 2018) who maintain that voters who are reminded of current and past promises reward incumbents who have fulfilled these past promises. Additionally, there is evidence that the reception of political promise by the public depends on the behaviour and traits of the politician. As pointed out by (Aragonès et al., 2007), the degree to which a political promise will be received by the public depends on the reputation of the politician. (Cruz et al., 2018) also assert that the public is more tolerant towards political promises when they perceive the political leader to be honest and competent.

Political mandate see (Owen \& Smith, 2018; Sieberer \& Ohmura, 2019) is the second identified step within the political leadership process. As suggested by (Shamir \& Shamir, 2010), political mandates are the link between the public and their elected representatives which normally originates from the public and finds its expression in the result of an election. (Morrell \& Hartley, 2006) describe political mandate as permission that is officially granted by an electorate to govern in accordance with stated policies. (Butcher \& Clarke, 2006) on the other hand, underscore the relevance of mandate by linking it to the deliberative ability of the political leader, they emphasise that the extent to which the public will trust the political representative to deliver their mandate depends on the degree of their inclusion. The ability of political leaders to effectively interact with the public is also an essential activity transforms traditional understanding of democratic mandate (Torfing \& Sørensen, 2019).

The third identified step within the political leadership process is representation. Representative process of political leadership involves development of a relationship between two parties with multilevel rights and responsibilities that has recognisable beginning and end (Andonov et al., 2018; Traber et al. 2018; Conti et al., 2018). The Stanford Encyclopedia of Philosophy describes political representation as "the activity of making citizens" voices, opinions, and perspectives 'present' in public policy making process", and further outlined the process to include; 1) a representing party, which could be an individual, an organisation, a movement, or a state agency; 2) a represented party, which includes constituents or clients; 3) a represented interest, opinion, discourse, or perspective; 4) a political context within which the process of representation occurs; and 5) perspectives and interests that are left out. (Horton, 2007) opines that political representation is central to the functionality of a political leader, as is (Powell Jr., 2004) who asserts that democratic representation requires that policy makers are supposed to meet the aspirations of the people they represent. (Dalton et al., 
2011) also opine that representation seeks to perform two essential functions, which are to ensure government accountability to the electorate and also to ensure broad distribution of the opinions of the citizens onto the legislature. By highlighting the role of "opinions of citizens", the contribution of (Dalton et al., 2011) attempt to link the deliberative and consultative perspectives discussed earlier to the political process. (Thompson, 2001) also attempts to find a connection between deliberation and the political process by describing political representation as a phenomenon involving three relationships: "1) between the representatives and the represented; 2) among the represented; and 3) among the representatives." (Thompson, 2001) provides a caveat to political representation by arguing that there is a tendency for political office holders to act in ways that promote their own re-election without consideration on the collective output of the legislature. In outlining the possibility of self-interest above public interest, (Thompson, 2001) argues that the behaviour or traits of a political leader may influence action within the political process.

The final step, and most common component of the political leadership process is causation. Causation is the analysis of cause and effect, see (Falleti \& Lynch, 2009; Garretsen et al., 2020; Louis et al., 2016; Körösényi et al., 2016). In other words, politicians engage in leadership roles in order to achieve political goals and objectives. It could be found that all the authors reviewed specified a motive necessitating political engagement. The following details were some of the perceived outcomes identified: protection of weaker stakeholders (Butcher \& Clarke, 2006), response to challenging events (De Clercy \& Ferguson, 2016), bridge the growing gap between the rich and the poor (Curry-Stevens, 2007), welfare expansion (Manor \& Duckett, 2017), social influence (Ammeter et al., 2002), public value outcomes (Torfing \& Sørensen, 2019), responsible use of public funds (Myerson, 2011), and empower the underprivileged (Bryder, 2001), while (Morrell \& Hartley, 2006) describe the outcome of political leadership activity from a viewpoint of influencing constitutional and legal framework.

\subsection{Political Leadership Process}

Having identified two themes which dominate literature on political leadership theory and four processes guiding its practice, we built these into one conceptual framework as shown in Figure 1 below. At its current state, our framework is empty both from analytical and empirical viewpoints. To put it in another way, it is does provide detail on the applicability or significance of these themes and processes. It also contains no emphasis on appositeness of ideas which can be applied to the models and processes. However, it does provide the groundwork for gathering and comparing evidence from scenarios which will enable us to confirm, refute or revise each of the models and processes. For example, scenario-based observations and survey which is used in simplifying complex interrelationships will enable us to demonstrate whether the themes identified provide a reliable basis for further study. 


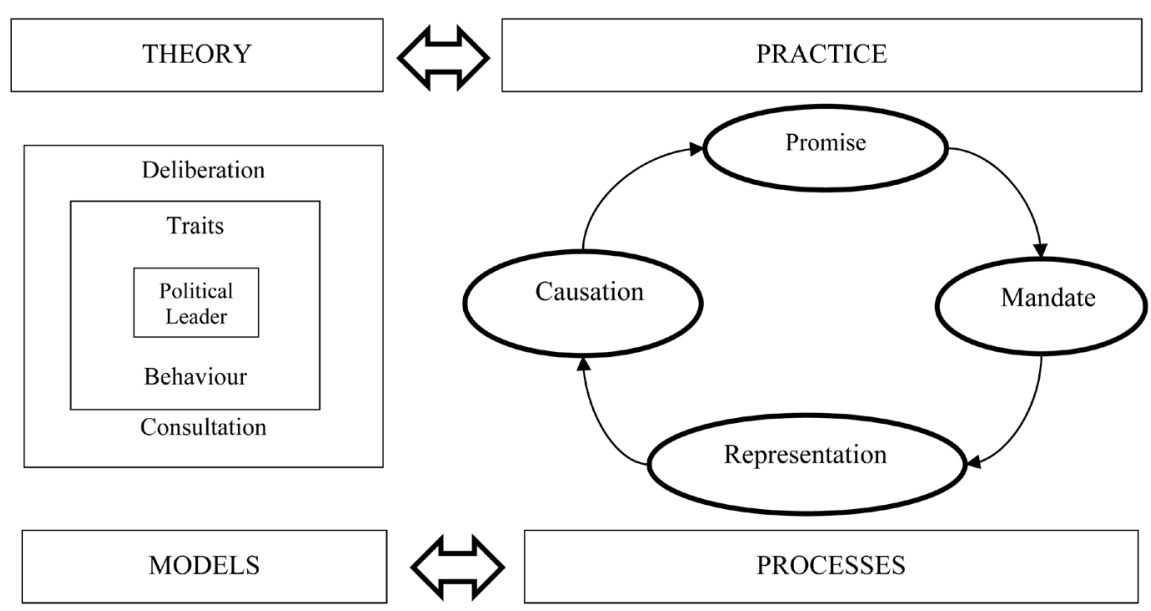

Figure 1. Proposed conceptual framework of political leadership theory and practice.

Even though our framework lacks depth on the identified components, we have built it to demonstrate our present belief about the theory and practices that shape political leadership. We believe political leadership is a cyclical, multifaceted and interdisciplinary activity, which is influenced by personal attributes and societal interferences, see (Ferris et al., 2017; Platow et al., 2017; McAllister et al., 2018). Our framework therefore allows for instances where, for example, discussions on the failures or success of political leaders depend on their ability to combine a wide range of factors such as personal skills, people skills, and administrative skills in seeking and executing political obligation. It allows for distinct themes to happen at the same time in multiple ways and also to happen more than once within the political environment. Based on the foregoing, the researchers attempt a proposed model for political leadership theory and practice presented in Figure 1.

The researchers depict Figure 1 as an attempt to diagrammatically present the outcome of the study.

On one hand, there are two main concepts that characteristically determine political leadership i.e. theory and model. On models and theories, literature shows that the two main areas of study that determine the aptitude of a political leader center on behaviour and traits. In order words, the innate characteristics of the political leader are the immediate factors that determine ability, talent, skill, knowledge, etc. These innate qualities or values must however be utilised through consultations and deliberations with external stakeholders such as the electorate and political parties to ensure attainment of set goals. This concept is depicted on the right side of the diagram.

On the other hand, political leadership as an operational function depends on practice and processes. Literature dictates that the function of the political leader (which is cyclical) commences with 1) the promise made by the political leader to deliver a set of goals; 2 ) receives a mandate that enables him/her to endeavour to achieve those goals; 3 ) utilises representation in the form of the executive, legislature and the judiciary to achieve these goals; 4) performance in fulfilment of 
the set goals by the political leader determines the extent of his/her influence and impact which largely determines future electoral fortunes and essentially the continuation of the cycle. This phenomenon is illustrated on the left side of the diagram.

Finally, there exists a dual dimensional interrelationship between theory and practice, as well as between models and processes so much so that it is ineffectual to decouple this taxonomy without altering the crux of the phenomenon.

\section{Conclusion}

Combing through the wide range of literature on political leadership can be confusing and daunting for researchers who are pursuing an understanding of political leadership theory and practice. However, we have demonstrated that the literature can be used as the basis to identify simplified themes and processes which form part of a multidisciplinary political leadership cycle which may include: political promise; mandate; representation; and causation. We have also demonstrated that these activities are influenced by the internal and external environment of the political leader.

\section{Limitation and Study Forward}

Although the researchers have been able to include these themes and ideas in a conceptual framework of political leadership, their associated implications and relevance remain currently unidentified or ambiguous at best. Based on this uncertainty, we recommend that empirical and analytical study in the future should be intended towards modifying and challenging each of the themes of the political leadership character and function that we have proffered. For this reason, this research is using this conceptual framework as a basis for evidence gathering from relevant cases and scenario-based studies with the goal of designing an improved model for political leadership theory and practice for the future.

The researchers are of the belief that this study will provide some insights on the character and function of political leadership and how these affect theory, practice, models, and processes.

\section{Conflicts of Interest}

The authors declare no conflicts of interest regarding the publication of this paper.

\section{References}

Akuffo, I. N., \& Kivipõld, K. (2017). Leadership Behaviour in the Context of Nepotism, Cronyism, and Favouritism: A Review of the Literature. In S. Morison (Ed.), Leadership for Improvement Perceptions, Influences and Gender Differences (pp. 255-282). Hauppauge, NY: NOVA Publishers.

Aloor, R. (2020). Political Economy of Social Vulnerability: A Study on Livelihood Vulnerabilities and Struggles of Traditional Potters in Kerala, India. Loyola Journal of Social Sciences, 34, 69-90. 
Álvarez-Díaz, A., Gonzalez, L., \& Radcliff, B. (2010). The Politics of Happiness: On the Political Determinants of Quality of Life in the American States. The Journal of Politics, 72, 894-905. https://www.journals.uchicago.edu/doi/10.1017/S0022381610000241 https://doi.org/10.1017/S0022381610000241

Ammeter, A. P., Douglas, C., Gardner, W. L., Hochwarter, W. A., \& Ferris, G. R. (2002). Toward a Political Theory of Leadership. The Leadership Quarterly, 13, 751-796. https://doi.org/10.1016/S1048-9843(02)00157-1

Anderson, C. J., \& Guillory, C. A. (1997). Political Institutions and Satisfaction with Democracy: A Cross-National Analysis of Consensus and Majoritarian Systems. American Political Science Review, 91, 66-81. https://doi.org/10.2307/2952259

Andonov, A., Hochberg, Y. V., \& Rauh, J. D. (2018). Political Representation and Governance: Evidence from the Investment Decisions of Public Pension Funds. The Journal of Finance, 73, 2041-2086. https://doi.org/10.1111/jofi.12706

Andrew, E. G. (2016). Heidegger's Führerprinzip: Leadership Out of and Into Nihilism. In M. A. Molchanov \& J. Masciulli (Eds.), The Ashgate Research Companion to Political Leadership (pp. 143-154). London: Routledge. https://doi.org/10.4324/9781315613406-14

Aragonès, E., Postlewaite, A., \& Palfrey, T. (2007). Political Reputations and Campaign Promises. Journal of the European Economic Association, 5, 846-884. https://doi.org/10.1162/JEEA.2007.5.4.846

Bates, R. (2005). Political Reform. CID Working Paper Series, Cambridge, MA: Harvard University.

Beerbohm, E. (2015). Is Democratic Leadership Possible? American Political Science Review, 109, 639-652. https://doi.org/10.1017/S0003055415000398

Bennister, M., Hart, P. T., \& Worthy, B. (2015). Assessing the Authority of Political Office-Holders: The Leadership Capital Index. West European Politics, 38, 417-440. https://doi.org/10.1080/01402382.2014.954778

Bennister, M., Worthy, B., \& Hart, P. T. (Eds.) (2017). The Leadership Capital Index: A New Perspective on Political Leadership. Oxford, England: Oxford University Press. https://doi.org/10.1093/oso/9780198783848.001.0001

Braun, V., \& Clarke, V. (2012). Thematic Analysis. In H. Cooper, P. M. Camic, D. L. Long, A. T. Panter, D. Rindskopf, \& K. J. Sher (Eds.), APA Handbook of Research Methods in Psychology, Vol. 2: Research Designs: Quantitative, Qualitative, Neuropsychological, and Biological (pp. 57-71). Washington DC: American Psychological Association.

Bryder, T. (2001). Motivational Approaches to the Study of Political Leadership. Political Science, 104, 115-137.

Burns, J. M. (1978) Leadership. New York, YK: Harper \& Row.

Butcher, D., \& Clarke, M. (2006). Political Leadership in Democracies: Some Lessons for Business? Management Decision, 44, 985-1001. https://doi.org/10.1108/00251740610690577

Castleberry, A., \& Nolen, A. (2018). Thematic Analysis of Qualitative Research Data: Is It as Easy as It Sounds? Currents in Pharmacy Teaching and Learning, 10, 807-815. https://doi.org/10.1016/j.cptl.2018.03.019

Conti, N., Hutter, S., \& Nanou, K. (2018). Party Competition and Political Representation in Crisis: An Introductory Note. Party politics, 24, 3-9.

https://doi.org/10.1177/1354068817740758 
Cook, B. J. (1998). Politics, Political Leadership, and Public Management. Public Administration Review, 58, 225-230. https://doi.org/10.2307/976562

Cornell, C., \& Malcomson, P. (2016). Prudence and Glory: Machiavelli on Political Leadership. In J. Masciulli, M. A. Molchanov, \& W. A. Knight (Eds.), The Ashgate Research Companion to Political Leadership (pp. 51-64). Farnham and Burlington, VT: Ashgate.

Cruz, C., Keefer, P., Labonne, J., \& Trebbi, F. (2018). Making Policies Matter: Voter Responses to Campaign Promises (No. w24785). National Bureau of Economic Research. https://doi.org/10.3386/w24785

Curry-Stevens, A. (2007). Pedagogy for the Privileged: Building Civic Virtues in Political Leaders. Journal of Transformative Education, 5, 33-58.

https://doi.org/10.1177/1541344607299394

Dalton, R. J., Farrell, D. M., \& McAllister, I. (2011). Political Parties and Democratic Linkage: How Parties Organize Democracy. Oxford, England: Oxford University Press. https://doi.org/10.1093/acprof:osobl/9780199599356.001.0001

De Clercy, C., \& Ferguson, P. (2016). Leadership in Precarious Contexts: Studying Political Leaders after the Global Financial Crisis. Politics and Governance, 4, 104-114. https://doi.org/10.17645/pag.v4i2.582

De Mesquita, B. B., Morrow, J. D., Siverson, R. M., \& Smith, A. (2002). Political Institutions, Policy Choice and the Survival of Leaders. British Journal of Political Science, 34, 559-590. https://doi.org/10.1017/S0007123402000236

Elgie, R. (2017). Political Leadership: A Pragmatic Institutionalist Approach. New York: Springer.

Enikolopov, R., \& Zhuravskaya, E. (2007). Decentralization and Political Institutions. Journal of Public Economics, 91, 2261-2290. https://doi.org/10.1016/j.jpubeco.2007.02.006

Falleti, T. G., \& Lynch, J. F. (2009). Context and Causal Mechanisms in Political Analysis. Comparative Political Studies, 42, 1143-1166. https://doi.org/10.1177/0010414009331724

Ferris, G. R., Perrewé, P. L., Daniels, S. R., Lawong, D., \& Holmes, J. J. (2017). Social Influence and Politics in Organizational Research: What We Know and What We Need to Know. Journal of Leadership \& Organizational Studies, 24, 5-19. https://doi.org/10.1177/1548051816656003

Fielding, D. (1997). Aggregate Investment in South Africa: A Model with Implications for Political Reform. Oxford Bulletin of Economics and Statistics, 59, 349-369. https://doi.org/10.1111/1468-0084.00070

Gane, N. (1997). Weber on the Ethical Irrationality of Political Leadership. Sociology, 31, 549-564. https://doi.org/10.1177/0038038597031003010

Ganuza Fernández, E. (2012). The Deliberative Challenge. In I. Ramos, \& E. Campos (Eds.), Citizenship in 3D: Digital Deliberative Democracy (pp. 19-50). Madrid: Fundacion Ideas and Foundation for European Progressive Studies.

Garfield, Z. H., von Rueden, C., \& Hagen, E. H. (2019). The Evolutionary Anthropology of Political Leadership. The Leadership Quarterly, 30, 59-80. https://doi.org/10.1016/j.leaqua.2018.09.001

Garretsen, H., Stoker, J. I., \& Weber, R. A. (2020). Economic Perspectives on Leadership: Concepts, Causality, and Context in Leadership Research. The Leadership Quarterly, 31, Article ID: 101410. https://doi.org/10.1016/j.leaqua.2020.101410

Gerring, J., \& Thacker, S. C. (2004). Political Institutions and Corruption: The Role of 
Unitarism and Parliamentarism. British Journal of Political Science, 34, 295-330. https://doi.org/10.1017/S0007123404000067

Harriss, J. (2000). How Much Difference Does Politics Make? Regime Differences across Indian States and Rural Poverty Reduction. Development Studies Institute, London School of Economics and Political Science.

Hartley, J. (2012). Political Leadership and Its Development. In A. Weinberg (Ed.), The Psychology of Politicians (pp. 97-120). Cambridge, England: Cambridge University Press. https://doi.org/10.1017/CBO9781139026482.008

Helms, L. (2017). Introduction: Leadership Questions on Transnational European Governance. European Political Science, 16, 1-13. https://doi.org/10.1057/eps.2015.113

Hendriks, C. M. (2009). Deliberative Governance in the Context of Power. Policy and Society, 28, 173-184. https://doi.org/10.1016/j.polsoc.2009.08.004

Horton, J. (2007). Political Leadership and Contemporary Liberal Theory. In J. Femia, A. Korosenyi, \& G. Slomp (Eds.), Political Leadership: A Missing Link Element in Democratic Theory (pp. 11-30). Exeter: Imprint Academic.

Ishii, K. (2010). Theory of Political Leadership. Mejiro Journal of Humanities, 6, 61-74.

Ishii, K. (2011). Analysis of Political Leadership using the Questionnaire Method. Mejiro Journal of Humanities, 7, 75-85.

Joensuu, M., \& Niiranen, V. (2018). Political Leaders and Public Administrators: Interaction Patterns and Pictures in Finnish Local Government Decision-Making Processes. Public Policy and Administration, 33, 22-45. https://doi.org/10.1177/0952076716673898

King, A. S. N., Millanzi, M., Massoi, L., \& Kyando, N. (2015). The Role of Political Leaders in Enhancing Peace and Tranquility: Thinking Big. International Journal of Managerial Studies and Research, 3, 84-90.

Kirvalidze, N., \& Samnidze, N. (2016). Political Discourse as a Subject of Interdisciplinary Studies. Journal of Teaching and Education, 5, 161-170.

Knight, W. A. (2016). Distinguishing and Unifying Visionary Leadership and Mechanical Management. In J. Masciulli, M. A. Molchanov, \& W. A. Knight (Eds.), The Ashgate Research Companion to Political Leadership (pp. 135-148). Farnham and Burlington, VT: Ashgate.

Körösényi, A., Illés, G., \& Metz, R. (2016). Contingency and Political Action: The Role of Leadership in Endogenously Created Crises. Politics and Governance, 4, 91-103. https://doi.org/10.17645/pag.v4i2.530

Lee, S. J. (1991). Political Liberalization and Economic Development in South Korea. Korea Journal of Population and Development, 20, 77-100.

Lees-Marshment, J. (2016). Deliberative Political Leaders: The Role of Policy Input in Political Leadership. Politics and Governance, 4, 25-35. https://doi.org/10.17645/pag.v4i2.560

Louis, W. R., La Macchia, S. T., Amiot, C. E., Thomas, E. F., Blackwood, L. M., Mavor, K. I., \& Saeri, A.(2016). Causality in the Study of Collective Action and Political Behaviour. In F. M. Moghaddam \& R. Harré (Eds.), Causes and Consequences: A multidisciplinary exploration (pp. 277-302). Santa Barbara, California, CA: Praeger.

Manor, J. (2004). Democratisation with Inclusion: Political Reforms and People's Empowerment at the Grassroots. Journal of Human Development, 5, 5-29. https://doi.org/10.1080/14649880310001660193

Manor, J., \& Duckett, J. (2017). The Significance of Political Leaders for Social Policy Ex- 
pansion in Brazil, China, India and South Africa. Commonwealth \& Comparative Politics, 55, 303-327. https://doi.org/10.1080/14662043.2017.1327926

Markwat, N. (2014). Who Believes That Political Parties Keep Their Promises? SOM-Rapport, 63, 331-334.

Masciulli, J., \& Knight, W. A. (2016). Conceptions of Global Leadership for Contextually Intelligent, Innovatively Adaptive Political Leaders. In J. Masciulli, M. A. Molchanov, \& W. A. Knight (Eds.), The Ashgate Research Companion to Political Leadership (pp. 89-122). Farnham and Burlington, VT: Ashgate.

McAllister, C. P., Ellen III, B. P., \& Ferris, G. R. (2018). Social Influence Opportunity Recognition, Evaluation, and Capitalization: Increased Theoretical Specification through Political Skill's Dimensional Dynamics. Journal of Management, 44, 1926-1952. https://doi.org/10.1177/0149206316633747

Moe, T. M. (2005). Power and Political Institutions. Perspectives on Politics, 3, 215-233. https://doi.org/10.1017/S1537592705050176

Molchanov, M. A. (2016). Classical Eastern and Western Traditions of Political Leadership. In J. Masciulli, M. A. Molchanov, \& W. A. Knight (Eds.), The Ashgate Research Companion to Political Leadership (pp. 31-50). Farnham and Burlington, VT: Ashgate.

Morrell, K., \& Hartley, J. (2006). A Model of Political Leadership. Human Relations, 59, 483-504. https://doi.org/10.1177/0018726706065371

Munro, I., \& Thanem, T. (2018). The Ethics of Affective Leadership: Organizing Good Encounters without Leaders. Business Ethics Quarterly, 28, 51-69.

https://doi.org/10.1017/beq.2017.34

Myerson, R. (2011). Toward a Theory of Leadership and State Building. Proceedings of the National Academy of Sciences of the United States of America, 108, 21297-21301. https://doi.org/10.1073/pnas.1019397108

Myres, R. (2016). Political Leadership and the Problem of Principle: A Classical Response to Postmodernism. In J. Masciulli, M. A. Molchanov, \& W. A. Knight (Eds.), The Ashgate Research Companion to Political Leadership (pp. 51-64). Farnham and Burlington, VT: Ashgate.

Nowell, L. S., Norris, J. M., White, D. E., \& Moules, N. J. (2017). Thematic Analysis: Striving to Meet the Trustworthiness Criteria. International Journal of Qualitative Methods, 16. https://doi.org/10.1177/1609406917733847

Owen, D., \& Smith, G. (2018). Sortition, Rotation, and Mandate: Conditions for Political Equality and Deliberative Reasoning. Politics \& Society, 46, 419-434. https://doi.org/10.1177/0032329218789892

Paldam, M. (1998). Does Economic Growth Lead to Political Stability? In S. Borner, \& M. Paldam (Eds.), The Political Dimension of Economic Growth (pp. 171-190). London: Palgrave Macmillan. https://doi.org/10.1007/978-1-349-26284-7_9

Paramova, P., \& Blumberg, H. (2017). Cross-cultural Variation in Political Leadership styles. Europe's Journal of Psychology, 13, 749-766.

https://doi.org/10.5964/ejop.v13i4.1412

Peele, G. (2005). Leadership and Politics: A Case for a Closer Relationship? Leadership, 1, 187-204. https://doi.org/10.1177/1742715005051858

Pierre, J., \& Peters, B. G. (2019). Governance, Politics and the State. London: Red Globe Press.

Platow, M. J., Haslam, S. A., \& Reicher, S. D. (2017). The Social Psychology of Leadership. In S. G. Harkins, K. D. Williams, \& J. M. Burger (Eds.), Oxford Library of Psychology. The Oxford Handbook of Social Influence (pp. 339-357). Oxford, England: Oxford University Press. 
Powell Jr., G. B. (2004). Political Representation in Comparative Politics. Annual Review of Political Science, 7, 273-296. https://doi.org/10.1146/annurev.polisci.7.012003.104815

Prokhovnik, R. (2009). Political Leadership and Sovereignty. In F. Joseph, K. Andras, \& S. Gabriella (Eds.), Political Leadership in Liberal and Democratic Theory (pp. 151-176). Exeter, UK: Imprint Academi,.

Radu, M. (2015). The Impact of Political Determinants on Economic Growth in CEE Countries. Procedia-Social and Behavioral Sciences, 197, 1990-1996. https://doi.org/10.1016/j.sbspro.2015.07.579

Rakner, L., Menocal, A. R., \& Fritz, V. (2007). Democratisation's Third Wave and the Challenges of Democratic Deepening: Assessing International Democracy Assistance and Lessons Learned. ODI Working and Discussion Papers, London, UK: Overseas Development Institute (ODI).

Rontos, K., Salvati, L., \& Vavouras, I. (2013). Socioeconomic and Political Dimensions of Development Worldwide. Sociology and Criminology, 1, 1-8.

Sahn, D. E., \& Stifel, D. C. (2003). Urban-Rural Inequality in Living Standards in Africa. Journal of African Economies, 12, 564-597. https://doi.org/10.1093/jae/12.4.564

Saideman, S. M., Lanoue, D. J., Campenni, M., \& Stanton, S. (2002). Democratization, Political Institutions, and Ethnic Conflict: A Pooled Time-Series Analysis, 1985-1998. Comparative Political Studies, 35, 103-129.

https://doi.org/10.1177/001041400203500108

Scalapino, R. A. (1992). National Political Institutions and Leadership in Asia. Washington Quarterly, 15, 157-172. https://doi.org/10.1080/01636609209550126

Schoen, D. E. (2013). The End of Authority: How a Loss of Legitimacy and Broken Trust Are Endangering Our Future. Lanham, MD: Rowman \& Littlefield.

Sedehi, A., \& Tabriztchi, S. (1974). A Theory of Economic Growth and Political Development: The Case of Iran. International Studies, 13, 424-440.

https://doi.org/10.1177/002088177401300303

Shamir, M., \& Shamir, J. (2010). Mandate Election Interpretations: Structural Foundations and Social Construction. Israel Science Foundation.

Sieberer, U., \& Ohmura, T. (2019). Mandate Type, Electoral Safety, and Defections from the Party line: The Conditional Mandate Divide in the German Bundestag, 1949-2013. Party Politics, 27, 704-715. https://doi.org/10.1177/1354068819881637

Sjoberg, L. (2016). Feminist Approaches to the Study of Political Leadership. In M. A. Molchanov \& J. Masciulli (Eds.), The Ashgate Research Companion to Political Leadership (pp. 169-194). London: Routledge. https://doi.org/10.4324/9781315613406-16

Solovyov, A. I. (2017). Political Leader in the Public Administration Environment, or Who Is the Man of the House? Political Studies, 2, 60-81.

Teles, F. (2012). Political Leaders: The Paradox of Freedom and Democracy. Revista Enfoques, 10, 113-131.

Thompson, D. F., Smelser, N. J., \& Baltes, P. B. (2001). Political Representation. In N. J. Smelser, \& P. B. Baltes (Eds.), International Encyclopedia of the Social and Behavioral Sciences (pp. 11696-11698). Oxford: Pergamon. https://doi.org/10.1016/B0-08-043076-7/01228-6

Titley, S. (2003). How Political and Social Change Will Transform the EU Public Affairs Industry. Journal of Public Affairs, 3, 83-89. https://doi.org/10.1002/pa.136

Tömmel, I., \& Verdun, A. (2017). Political Leadership in the European Union: An Intro- 
duction. Journal of European Integration, 39, 103-112. https://doi.org/10.1080/07036337.2016.1277714

Torfing, J., \& Ansell, C. (2017). Strengthening Political Leadership and Policy Innovation through the Expansion of Collaborative forms of Governance. Public Management Review, 19, 37-54. https://doi.org/10.1080/14719037.2016.1200662

Torfing, J., \& Sørensen, E. (2019). Interactive Political Leadership in Theory and Practice: How Elected Politicians May Benefit from Co-Creating Public Value Outcomes. Administrative Sciences, 9, 51. https://doi.org/10.3390/admsci9030051

Torfing, J., Sørensen, E., \& Røiseland, A. (2019). Transforming the Public Sector into an Arena for Co-Creation: Barriers, Drivers, Benefits, and Ways Forward. Administration \& Society, 51, 795-825. https://doi.org/10.1177/0095399716680057

Traber, D., Giger, N., \& Häusermann, S. (2018). How Economic Crises Affect Political Representation: Declining Party-Voter Congruence in Times of Constrained Government. West European Politics, 41, 1100-1124.

https://doi.org/10.1080/01402382.2017.1378984

Van Zuydam, S. (2014). Credibility as a Source of Political Capital: Exploring Political Leaders' Performance from a Credibility Perspective. In Political Capital and the Dynamics of Leadership: Exploring the Leadership Capital. UK: European Consortium for Political Research Joint Sessions.

Van Zuydam, S., \& Hendriks, F. (2018). Credibility Enacted: Understanding the Meaning of Credible Political Leadership in the Dutch Parliamentary Election Campaign of 2010. Journal of Political Marketing, 17, 258-281. https://doi.org/10.1080/15377857.2015.1039747

Ward, V., House, A., \& Hamer, S. (2009). Developing a Framework for Transferring Knowledge into Action: A Thematic Analysis of the Literature. Journal of health services research \& policy, 14, 156-164. https://doi.org/10.1258/jhsrp.2009.008120

Weingast, B. R. (1995). The Economic Role of Political Institutions: Market-Preserving Federalism and Economic Development. Journal of Law, Economics, \& Organization, 11, 1-31.

Williams, G., Duncan, A., Landell-Mills, P., \& Unsworth, S. (2009). Politics and Growth. Development Policy Review, 27, 5-31. https://doi.org/10.1111/j.1467-7679.2009.00433.x

Yan X. (2016). Political Leadership and Power Redistribution. The Chinese Journal of International Politics, 9, 1-26. https://doi.org/10.1093/cjip/pow002

Yukl, G. (2002). Leadership in Organisations (5th ed.). Hoboken, NJ: Practice Hall. 